market in the next few years. What the government has to decide is what kind of computer industry it wants to have ten years from now and how much it is prepared to pay in development costs to achieve that target. It is unthinkable, in present circumstances, that British companies could succeed independently of their competitors in Europe, and even if it did, it would find itself hamstrung by the procurement policy of European governments. The moral is that the British government should abandon its protection of the domestic market and throw its weight, instead, into the building of a European computer industry.

\section{Muddle in America}

IT is improbable that the American government, the Administration and Congress lumped together, knows how foolish its budgetary procedures make it seem. After ten months of fierce argument, it now seems to have been accepted in Congress that the battle to force an increased rate of spending on the Administration in health and education has been lost. Our Washington Correspondent reports this week (see page 81) that Congress and the Administration have finally reached a stalemate on the Health, Education and Welfare Bill, as a result of which the level of spending during the current fiscal year (with less than four months to run) will be pegged at what it was last year. Among the scientific organizations seriously affected will be the National Institutes of Health, which have in the past eight months been uplifted first by the Administration's own request for a higher rate of spending and then by Congress's show of still greater generosity and finally have found themselves pegged back to a rate of expenditure essentially the same as that specified in the inadequate budgets for 1971-72. The difficulties that this will cause are easily imagined. Having committed themselves to some of the plans drawn up when it seemed that the budget would be generous, the National Institutes of Health will now find it necessary to cut back on other programmes in principle just as worthy. Moreover, it is programmes in principle just as worthy.

Battles over the budget for the Department of Health, Education and Welfare are, of course, a traditional part of the congressional year. Just as the department itself is accurately known as the antheap, so its annual budget creates a greater variety of controversial issues which may be delayed in Congress itself by arguments over questions such as the bus-ing of negro children to white schools and in the White House if Congress should have committed itself to fancy schemes for spending money that the President disapproves of. In the past, the budget of the National Science Foundation has frequently been delayed and even emasculated simply because it is a part of the vast compendium of legislation covering the Departments of Health, Education and Welfare. This year, it is the $\mathrm{NIH}$ that suffers. What Congress and the Administration should acknowledge is that capricious accidents like these are not merely a guarantee of inefficient expenditure but also a great source of demoralization among scientific workers. Yet on the face of things, the way out of this kind of difficulty would seem simple enough. Even though the Department of Health, Education and Welfare is a single entity in the government (which should be broken up), is there any reason why the budgets for the several components of the department should not be separately presented, argued over independently in Congress and then approved (or vetoed, since that seems to be President Nixon's predilection) on their own? In the old days, in the 1960s, American administrators were continually arguing over the best means of constructing a national science policy. They have rightly rejected the idea that there should be an executive department with responsibility in this field, but they should now acknowledge that the repeated muddle over important parts of the science budget is not merely an assurance that there will never be a coherent science policy but that those agencies responsible for executing scientific work will carry the burden for the government's administrative foolishness.

\section{Years Ago}

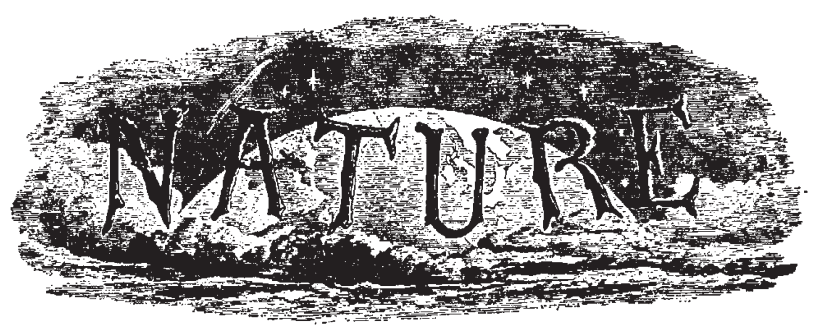

Perception in the Lower Animals

As several persons seem interested in Mr. Wallace's suggestion that animals find their way home by recognising the odour of the places which they have passed whilst shut up, you may perhaps think the following little fact worth giving. Many years ago I was on a mail-coach, and as soon as we came to a public-house, the coachman pulled up for the fraction of a second. He did so when we came to a second public-house, and I then asked him the reason. He pointed to the off-hand wheeler, and said that she had been long completely blind, and she would stop at every place on the road at which she had before stopped. $\mathrm{He}$ had found by experience that less time was wasted by pulling up his team than by trying to drive her past the place, for she was contented with a momentary stop. After this I watched her, and it was evident that she knew exactly, before the coachman began to pull up the other horses, every public-house on the road, for she had at some time stopped at all. I think there can be little doubt that this mare recognised all these houses by her sense of smell. With respect to cats, so many cases have been recorded of their returning from a considerable distance to their homes, after having been carried away shut up in baisets, that I can hardly disbelieve them, though these stories are disbelieved by some persons. Now, as far as I have observed, cats do not possess a very acute sense of smell, and they seem to discover their prey by eyesight and by hearing. This leads me to mention another trifling fact : I sent a ridinghorse by railway from Kent vici Yarmouth, to Freshwater Bay, in the Isle of Wight. On the first day that I rode eastward, my horse, when I turned to go home, was very unwilling to return towards his stable, and he several times turned round. This led me to make repeated trials, and every time that I slackened the reins, he turned sharply round and began to trot to the eastward by a little north, which was nearly in the direction of his home in Kent. I had ridden this horse daily for several years, and ne had never before behaved in this manner. My impression was that he somehow knew the direction whence he had been brought. I should state that the last stage from Yarmouth to Freshwater is almost due south, and along this road he had been ridden by my groom; but he never once showed any wish to return in this direction. I had purchased this horse several years before from a gentleman in my own neighbourhood, who had possessed him for a considerable time. Nevertheless it is possible, though far from probable, that the horse may have been born in the Isle of Wight. Even if we grant to animals a sense of the points of the compass, of which there is no evidence, how can we account, for instance, for the turtles which formerly congregated in multitudes, only at one scason of the year, on the shores of the Isle of Ascension, finding their way to that speck of land in the midst of the great Atlantic Ocean?

Charles Darwin 